\title{
Focus in Yorùbá: a semantic/pragmatic account ${ }^{1}$
}

\author{
Susie Jones \\ University of British Columbia
}

\begin{abstract}
Semantic and pragmatic properties of the Yorùbá focus construction have not been fully examined. This paper investigates presupposition, exhaustivity effects, and felicity conditions in some of its attested forms. Yorùbá focus does not trigger existence presuppositions, it does not have any obligatory exhaustivity effects, and argument focus and predicate focus behave differently with respect to questionanswer congruence. These properties are compatible Déchaine's analysis (2002) of Yorùbá focus as inverse predication, essentially a type of cleft.
\end{abstract}

\section{$1 \quad$ Introduction}

Focus is a grammatical means of marking the organization of information in discourse. It divides sentences into a focus and an open proposition corresponding to background information. Focus selects a value for the variable in the open proposition from a set of contextually relevant alternative propositions (Rooth, 1996). In (1a) Ted is the focus, (1b) shows the open proposition, and (1c) shows the set of alternatives created by replacing $\mathrm{x}$ with a contextually relevant individual:
(1)
a. Bill introduced $[\mathrm{Ted}]_{\mathrm{F}}$ to Mary.
Focus on Ted
b. Bill introduced $x$ to Mary
Open proposition
c. $\quad$ Bill introduced John to Mary, Bill introduced Sue
to Mary, Bill introduced Tim to Mary $\quad$ Set of alternatives

Focus is marked in various ways across languages: prosodically (English intonational focus), morphologically (Mandeng), or structurally (English cleft

1 I am very grateful to my consultant, Oládiípò Ajíboyè. All data, unless otherwise noted, is from my own fieldwork. 
focus, Yorùbá). In $]_{\mathrm{F}}$, the focus occupies the left position in the sentence, and is followed by the particle $n i$ :

(2) $[\mathrm{XP}]_{\mathrm{F}}$ ni $[\ldots]$

Examples of Yorùbá focus are in (3)-(7). When a subject is questioned or focused, a third person singular resumptive pronoun, $o$, is obligatory (Carstens 1985):

(3) Adẹ ni ó ra ìwé.

Ade FOC $^{2} 3$ sg buy book

'[Ade $]_{\mathrm{F}}$ bought a/the book.' $\quad$ Focus of subject

Questioned or focused objects leave a gap in object position (Déchaine 2002):

(4) İwé ni Adé rà

book FOC A. buy

'Adé bought $[\mathrm{a} / \text { the book }]_{\mathrm{F}}$.'

Focus of object

Verb/VP focus, or predicate clefting, is attested in Yorùbá. The verb or VP is nominalized via reduplication, and a copy of the verb is required in the construal site. in (5), rà (buy) is nominalized, and appears as rírà when focused:

(5) [Rírà $]_{\mathrm{F}}$ ni Adé ra ìwé.

NOM-buy FOC A. buy book

'Ade [bought $]_{\mathrm{F}}$ a/the book.'

Focus of verb

In VP focus, the focused verb and object are both copied in the construal site:

(6) [Rírà ìwé $]_{F}$ ni Adé ra ìwé.

NOM-buy FOC A. buy book

'Ade [bought a/the book. $]_{\mathrm{F}}$ '

Focus of VP

2 I have glossed $n i$ as FOC, for focus, in all contexts it occurs in. 
CPs can be focused:

(7) Pé ó ra ìwé ni èmi mọ̀.

COMP 3 sg buy book FOC 1 sg know

'[That he/she bought a book $]_{\mathrm{F}}$, I know.'

Focus of $\mathrm{CP}$

\section{Syntactic analysis of Yorùbá focus}

Yusuf (1990) proposed that Yorùbá focus is a type of copula, based on the distribution of the particle $n i$. Ni occurs in focus contexts such as (3) through (7), above. It also functions as a copular verb in certain nominal predications. Yorùbá has two copular verbs, $n i$ and jé, each used in different discourse contexts:

a. Kìnìn ni ọba ẹranko.

Lion FOC king animal

'The lion is the king of the animals.'

Answers: Which animal is king of the animals?

b. Kìnùn jẹ́ ẹranko ńlá

Lion be animal big

'The lion is a big animal.'

Answers: Tell me something about lions.

(Bisang \& Sonaiya 2000, p. 172)

$J e ́$ occurs in canonical copula sentences, and $n i$ occurs in inverse copula sentences. In an inverse copula sentence, also called an inverse predication, the predicate precedes the subject:
a. $\quad\left[{ }_{\text {SUBJ }} \mathrm{DP}{ }_{\mathrm{PRED}} \mathrm{XP}\right]$
Canonical nominal predication
b. $\quad\left[{ }_{\mathrm{PRED}} \mathrm{XP}{ }_{\text {SUBJ }} \mathrm{DP}\right]$
Inverse nominal predication

Déchaine (2002) proposed that focus constructions are also inverse predications. Her analysis treats focus more specifically as a type of cleft (henceforth called the cleft analysis). Previously, Yorùbá focus has been analyzed as focus movement, a variety of $\mathrm{A}^{\prime}$-movement in which the focused XP is moved from its canonical position to the specifier of a Focus Phrase (Awóyale 1985, Bisang and Sonaiya 2000, Aboh 2003).

This paper investigates the semantics and pragmatics of the Yorùbá focus construction, with the purpose of determining how they may inform the understanding of its syntax. First, I compare the basic claims of the cleft 
analysis with the focus movement analysis (as defined by Kiss (1998)), and compare how each captures the syntactic properties of Yorùbá. The following sections then examine presupposition, exhaustivity, and question-answer congruence in some Yorùbá focus constructions. I conclude that the cleft analysis is more compatible with the presuppositions and other pragmatic properties of Yorùbá focus.

\subsection{The cleft analysis (Déchaine 2002)}

Clefts are a type of copula construction associated with focus (Lambrecht 2001). The association of cleft sentences with focus is not unique to Yorùbá. English has at least two different types of clefts (Higgins 1973), it-clefts and pseudoclefts, both of which express focus ${ }^{3}$ :
a. It was [a book $]_{\mathrm{F}}$ that John bought.
It-cleft
b. What John bought was [a book $]_{\mathrm{F}}$.
Pseudocleft

Both answer: What did John buy?

As noted in the previous section, the particle $n i$ occurs in Yorùbá in both focused sentences and inverse predications that involve focus. An example of an inverse predication is (9a). The NP in the sentence-initial position, olópá, has a predicational (property-denoting) interpretation. The context question shows that the predicational NP is the focus of the sentence ${ }^{4}$ :

(11) Olọpá ni Adé.

police officer FOC Adé

'Ade is a police officer.'

Answers: What is Adé?

(Davison 1986)

Because $n i$ is associated with copula sentences that involve focus, Yusuf (1990) argued that focus sentences should also be treated as copulas. Based on the fact that $n i$ is associated with inverse copulas, Déchaine (2002) proposed an analysis that derives Yorùbá focus via predicate raising from a small clause:
a. [SUBJDP $\left.{ }_{\text {PRED }} \mathrm{XP}\right]$
b. $\quad[X P]_{i}$ ni $\left[{ }_{\text {SUBJ }} \mathrm{DP}{ }_{\text {PRED }} \mathrm{t}_{\mathrm{i}}\right]$

Predicate raising

3 See Lambrecht 2001 for additional types of clefts in English and other languages.

4 A test for whether an XP is the focus of a sentence is whether it provides the answer to a question (Kadmon 2001). 
In a canonical copula sentence, the subject of a small clause (SC) is raised to the subject position (Spec., Infl.) of the main clause (Heycock 1991). In inverse predication, the predicate of the small clause is raised to subject position of the main clause, instead. The cleft analysis treats a Yorùbá focused XP as a raised predicate. The focused XP is followed by the copula $n i$ :

(13) a. [ìwé $\left.{ }_{i}\right]_{\mathrm{F}}$ ni Adé rà

Book FOC A. buy

$=[\mathrm{A} \text { book }]_{\mathrm{F}}$ is what Adé bought. Focus construction (cleft)

b. Sc[subj (what) Adé rà _ ] [PRED ìwé] Small clause

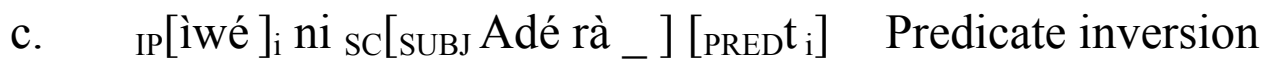

The subject of the focused sentence is the post- $n i$ information, analyzed as a free relative clause headed by pro:

(14) ni suBJ $\left[\right.$ DP $_{\text {pro }}\left[{ }_{\mathrm{CP}} \mathrm{Op}_{\mathrm{i}}\left[\mathrm{IP}\right.\right.$ Adé rà $\left.\left.\left.\mathrm{e}_{\mathrm{i}}\right]\right]\right]$

Free relative subject

Under the cleft analysis, the sentence-initial position of the focused XP is attributable to predicate raising. Resumptive pronouns in subject focus (as in example (3)) are attributable to relativization. The required nominalization of $\mathrm{V}$ and VP focus is attributable to inverse nominal predication, which only operates on nominal expressions (Déchaine 2002: 5).

\subsection{Focus movement (Kiss 1998)}

Kiss (1998) analyzes syntactic focus in Hungarian as focus movement. Focus movement is a type of $\mathrm{A}^{\prime}$-movement. This analysis assumes that Universal Grammar has a dedicated structural position in the clause for focus similar to the position dedicated to $w h$-phrases:
a. $\quad\left[\mathrm{CP} w h_{1}\left[\mathrm{IP} \ldots \mathrm{t}_{1} \ldots\right]\right]$
Wh-movement
b. $\quad\left[\right.$ FocP $\left.\mathrm{XP}_{1}\left[\mathrm{IP} \ldots \mathrm{t}_{1} \ldots\right]\right]$
Focus-movement

Yorùbá focus has previously been analyzed as involving focus movement. This type of analysis accounts for the sentence-initial position of the focused XP and for the presence of resumptive pronouns. However, focus movement does not account for the occurrence of $n i$ in both nominal predication and focus, or for the required nominalization of focused verbs and VPs. Moreover, Yorùbá focus contrasts with Hungarian focus in several ways: it is not exhaustive, it does not 
trigger existence presuppositions, and it is not restricted to argument expressions.

Kiss (1998) argues that it is necessary to distinguish between at least two kinds of focus. Syntactic focus involves focus movement, and it is restricted to the expression of identificational focus. Identificational focus is defined (in part) as focus with obligatory exhaustivity effects. Exhaustivity means the focused element picks out every individual identified with the variable in the open proposition. Identificational focus is contrasted with information focus, which does not involve movement and has no obligatorily exhaustivity effect. Yorùbá focus does not have obligatory exhaustivity, as will be shown in section 3.

In focus movement, restrictions are placed on the constituent that can occupy the focus position (Spec., FocP). This position is restricted to referential NPs: quantificational and predicational NPs are excluded. Moreover, "thatclauses, infinitival clauses, VPs and predicative NPs/AdjPs must also be excluded" (Kiss 1998: 261). Yorùbá verbs, VPs, CPs, and quantificational NPs may be focused.

\section{Yorùbá focus is not exhaustive}

Yorùbá focus is generally judged to provide an exhaustive answer to a question. However, the dialogue in (16) shows that this is a weak, cancellable exhaustivity ${ }^{5}$ :

(16) a. Speaker A: Ta ni ó lọ?

wh FOC 3sg go

'Who went?'

b. Speaker B: Akin ni ó lọ.

Akin FOC

'Akin went.'

c. Speaker A: Ta ni elo miràn ti ó lọ?

wh FOC somebody else COMP 3sg go

'Who else went?'

d. Speaker B: Adé ni.

Ade FOC

'Adé did.'

This test for exhaustivity is attributed to Bolinger (1972) by Lambrecht (2001 : p. 504). 
If the focused answer in (16b) were obligatorily exhaustive, then Speaker A's second question in (16c) should be judged infelicitous, for the following reason: Speaker A would know from (16b) that nobody else went. If Speaker A then asks (16c), infelicity arises from a violation of Grice's Cooperative principle (1975). The Maxim of Quantity requires that you make your contribution as informative as possible, but (16c) would force Speaker B to give a noninformative answer ("Nobody else went"). The fact that the dialogue is felicitous shows that the apparent exhaustivity in (16b) is a cancellable implicature, and not obligatory. Exhaustivity effects are also absent in focus of objects:

(17) a. Speaker A: Kí ni Adé rà?

Wh FOC A. buy

'What did Adé buy?'

b. Speaker B: ìwé ni Adé rà.

book FOC Adé buy

'Ade bought a book.'

c. Speaker A: Kí ni elo omíràn ó rà?

Wh FOC something else 3sg buy

'What else did he buy?'

d. Speaker B: Àwòran ni ó rà picture FOC 3sg buy

'He bought a picture.'

I take (16) and (17) as indications that focus does not involve obligatory exhaustivity in Yorùbá.

\subsection{Exhaustivity and the syntactic analysis}

The absence of obligatory exhaustivity in Yorùbá is not compatible with focusmovement as defined by Kiss (1998). However, there is also a contrast between Yorùbá focus and the corresponding English clefts, which are consistently judged to be exhaustive:

(18) Speaker A: Who went?

Speaker B: It was John who went.

Speaker A: \#Who else went? 
In the focus movement account, exhaustive identification is a direct consequence of $\mathrm{A}^{\prime}$-movement, where the focused XP moves to an operator position and binds its trace in the extraction site. This analysis consequently does not predict the absence of exhaustivity in Yorùbá focus. The cleft analysis better captures this absence, because other research shows that clefts are not uniform with respect to exhaustivity across languages.

\subsection{Clefts in two Salish languages}

Two languages unrelated to Yorùbá from different branches of the Salish family, Northern Straits and St'át'imcets, have clefts with only weak, cancellable exhaustivity (Davis, Matthewson, \& Shank 2004). Each language has two types of cleft construction, with different syntactic structures. The first type is "nominal predicate constructions," or NPC's. These consist of a nominal predicate and a headless relative clause introduced by a determiner (p. 100):
a. la s?n $\left[\mathrm{k}^{\mathrm{w}} \mathrm{s} \partial \mathrm{t}^{\prime} \mathrm{s}-\partial \mathrm{t}-\mathrm{s}\right.$
$\mathrm{k}^{\mathrm{w}} \mathrm{s} ə$ Richard]
plate [DET break-CTR-3.SUB DET Richard
'What Richard broke was a plate.' NPC: Straits

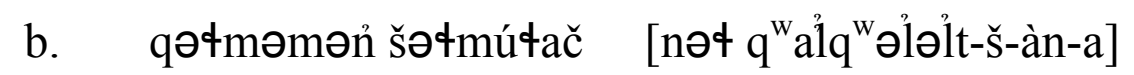
old person woman (PL) DET.PL speak-CAUS-1SG.ERG-DET 'The ones I spoke to were old women.' NPC: St'át'imcets (Davis, Matthewson \& Shank 2004: 102)

The second type is "introduced clefts" or simply "clefts," which include an introductory, pronoun-like predicate, analyzed as a copula (Kroeber 1999):
a. $\quad n i k^{\mathrm{w}}$ sə la s?n $\left[\mathrm{k}^{\mathrm{w}}\right.$ sə $\mathrm{t}^{\prime} \mathrm{s}-\partial \mathrm{t}-\mathrm{s}$
$\mathrm{k}^{\mathrm{w}} \mathrm{s} ə$ Richard] nit DET plate [DET break-CTR-3.SUB DET Richard] 'It was a plate Richard broke.'
Cleft: Straits

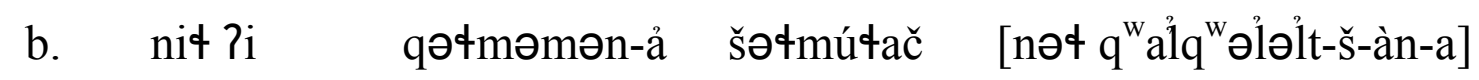
nił DET.PL old.person-DET woman(PL) [DET.PL speak-CAUS1SG.ERG-DET]

'It was the old women that I spoke to.'

Cleft: St'át'imcets

(Davis, Matthewson \& Shank 2004: 103)

In each language, neither construction triggers existence presuppositions, or gives rise to an obligatory exhaustivity effect. (21a) and (21b) are cleft 
sentences that include particles that correspond to "also" or "too" in English. The acceptability of these particles in each construction shows the absence of obligatory exhaustivity effects. The particles also and too do not co-occur with English clefts because they explicitly contradict exhaustivity:

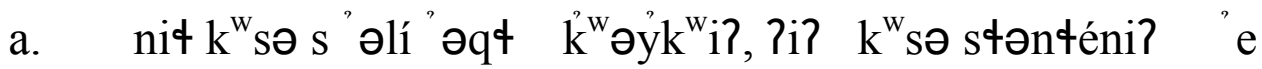 nit DET child(PL) hungry and DET woman(PL) too '??It's the kids that are hungry, and the ladies too. " Cleft: Straits

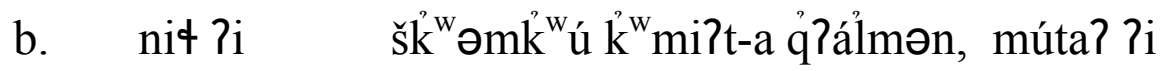
nit DET.PL child(PL)-DET eat-want and DET.PL lalíltəm-a "it adult-DET also
'??It's the children who are hungry, and also the adults.'
Cleft: St'át'imcets
(Davis, Matthewson \& Shank 2004: 110)

The translations of (21a-b) are ungrammatical, or at least odd, showing that clefts in English and clefts in Straits or St'át'imcets have different semantic properties. Both clefts and NPCs in Salish lack exhaustivity effects, and this is significant for the syntactic analysis of Yorùbá. Because the above data shows that the semantics of clefts differ across languages, the absence of exhaustivity in Yorùbá focus is not incompatible with a cleft analysis of the construction.

\section{$4 \quad$ Yorùbá focus has no existence presupposition}

Focus is generally considered to trigger a presupposition, but not necessarily an existential presupposition. (22a) appears to presuppose the existence of someone who likes Bill, and assert that this is Mary. However, intonational focus does not trigger existence presuppositions, because (22b) specifically asserts that there is nobody who likes Bill ${ }^{6}$ :

(22) a. MARY likes Bill.

b. NOBODY likes Bill.

(Kadmon 2001: 254)

6 Jackendoff concludes that the presupposition involved in sentences like these is that the set of people who like Bill is "coherent, or well-defined, or amenable to discussion, or under discussion" in the current discourse. Rooth proposes that focuspresupposes that there is another relevant alternative proposition in the discourse (Kadmon : p. 326-328). 
Yorùbá focus also does not trigger existence presuppositions. (23) asserts that nobody went, and as in (22b), the claim that someone exists who went is explicitly denied:

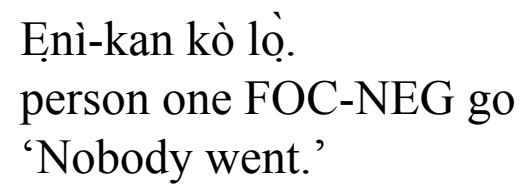

If Yorùbá focus triggered an existence presupposition, (24a) would be expected to be odd in the same way that the corresponding English clefts in (24b) are odd. It would mean that the presupposition and the assertion of the sentence were the same. But (24a) is grammatical and asserts, not presupposes, that someone went:

(24) a. Context question: Who went?

Enì kan ni ó lo.

Somebody FOC 3sg. go

'Somebody went.'

b. Context question: Who went?

*It was somebody who went.

*Who went was somebody.

Yorùbá focus is not contrastive in the sense meant by Kiss (1998). Contrastive focus in this sense presupposes not only the existence of an individual who satisfies the predicate, but also presupposes the existence of individuals who do not satisfy the predicate. Universal quantifiers are therefore not compatible with identificational focus (focus movement), because they do not accommodate the presupposition that there exist individuals who do not satisfy the predicate. (25a) shows that Yorùbá focus does not have the presuppositions of contrastive focus. The corresponding English clefts do have these presuppositions, because the universal quantifier is ungrammatical:

(25) a. Context question: Who went?

Olúkulùku ni wọn lọ.

Everybody went.

b. Context question: Who went?

*It was everybody who went.

*Who went was everyone.

(23)-(25) indicate that Yorùbá focus lacks existence presuppositions. 


\subsection{Presupposition and the syntactic analysis}

Among the expressions listed by Kiss that are excluded from identificational focus are the QPs someone or something and everyone or everything. These quantificational NPs are also excluded from English it-clefts, which Kiss classifies as identificational focus. The focus movement analysis does not capture the fact that quantificational NPs are fine in Yorùbá focus. However, English clefts are well known to trigger existence presuppositions (Percus 1997). If the cleft analysis of Yorùbá focus is correct, Yorùbá clefts contrast with English clefts in this respect.

\subsection{Yorùbá focused XPs and definiteness}

Percus (1997) proposes that the existence presupposition triggered by it-clefts is attributable to the fact that they contain a discontinuous definite description:

(26) a. It is $[\mathrm{John}]_{\mathrm{F}}$ that Mary saw.

b. [IP [DP the 0 [CP Op $p_{i}$ that Mary saw $\left.\left.t_{i}\right]\right]_{j}\left[\mathrm{vP}_{\mathrm{j}} \mathrm{t}_{\mathrm{j}}\right.$ is John]] Definite description is [DP the 0]

c. $\quad\left[\right.$ [IP $\left[D P \text { the } 0 t_{k}\right]_{j}\left[{ }_{\mathrm{VP}} \mathrm{t}_{\mathrm{j}}\right.$ is John $\left.\left.]\right]\left[\mathrm{CP} \mathbf{O} \mathbf{p}_{\mathbf{i}} \text { that Mary saw } \mathbf{t}_{\mathbf{i}}\right]_{\mathrm{k}}\right]$ Exptraposition of relative clause

d. Spell out: $\left[D P\right.$ the $\left.0 t_{k}\right] \rightarrow$ It

(Percus 1997)

Exhaustivity and existence presupposition follow from the uniqueness requirement of this definite description, which is represented by it (Percus 1997: $340)$. A cleft of the form $I t$ is $[\alpha]_{F}$ that has property $\Pi$ requires that $\forall \mathrm{x}(\Pi(\mathrm{x})$ $\rightarrow \mathrm{x}=\alpha$ ). In (26), John is identified as the unique individual who Mary saw. The cleft contains the definite description the 0 that has property $\Pi$ : in (26), the property is "someone who Mary saw." When this property is attributed to John, then for anyone who Mary saw, they have to be identical in reference to John.

Definite and indefinite NPs are bare in Yorùbá (Ajíbóyè 2005). In order to be construed as definite (as having existence and uniqueness presuppositions), a noun must be discourse linked (D-linked, Pesetsky 1987). This means its denotation is supplied by the discourse (Pesetsky 1987: 175-179). If a Yorùbá bare noun is not D-linked, it has a default indefinite interpretation.

Yorùbá focus contrasts with English cleft focus in that although both sentence types provide the answer to a question, Yorùbá answers do not obligatorily trigger existence presuppositions. Unless it answers a D-linked 
questions, the focused NP in the answer is not D-linked either. A D-linked question requires the speaker to choose their answer from a presupposed set of contextually relevant individuals. In English, D-linked questions ask Which N? Non D-linked questions ask Who/What? and do not presuppose a contextually restricted set. In Yorùbá, the focused XP in the answer to a ta ni/ki ni? (who/what?) question is not chosen from a presupposed set, and is therefore not construed as having existence or uniqueness presuppositions? ${ }^{7}$.

Because a Yorùbá focused XP is not definite unless it is D-linked, focus does not inlcude an existence presupposition. (27) is an example of how Dlinking triggers existence presuppositions: náà presupposes a restricted set of children who can dance:

Kúnlé àti Títí náà ni ó lè jó.

$\mathrm{K}$. and T. SALIENT FOC 3sg able dance.

'Only Kúnlé and Títí can dance.' (Ajíbóyè 2005: 207-208)

Percus attributes the existence presupposition in English cleft focus to a covert definite description. In Yorùbá, existence presuppositions are only triggered when an NP is D-linked; therefore, the absence of presupposition in Yorùbá focus is not incompatible with the cleft analysis.

\section{$5 \quad$ Focus and discourse congruence}

The constituent that is focused in an utterance determines the discourse contexts it can be used in felicitously (Kadmon 2001). In Yorùbá, there is a contrast between argument and predicate focus with respect to felicity conditions, specifically, question-answer congruence. Argument focus answers a corresponding wh-question; however, verb focus is infelicitous in questionanswer contexts.

Question-answer pairs demonstrate how the focus of a sentence determines its felicity conditions, that is to say, which question it answers. (28) shows how the constituent that is focused correlates with the wh-phrase in the question it answers:

a. Carl likes HERRING

Answers: What does Carl like?

Does not answer: Who likes herring?

It is expected that a which $N$ question in Yorùbá will trigger an existence presupposition, but this remains to be tested. 
b. CARL likes herring.

Answers: Who likes herring?

Does not answer: What does Carl like? (Kadmon 2001: 253-254)

Discourse congruence between focus sentences and the questions they answer follows from semantic parallels between focus and questions:

(29) a. A question denotes a set of propositions (Hamblin 1973).

b. Focus evokes a set of contextually relevant alternative propositions, created by replacing the focused element with some other contextually relevant element (Rooth 1996).

Rooth's analysis of focus explains the relationship between focus and questions. The set of alternatives evoked by focus is the "focus semantic value" or [[S] $]^{\mathrm{f}}$ of the sentence. Sentences have their usual semantic value, $[[\mathrm{S}]]^{0}$ plus their focus semantic value:

(30) $\left[\left[\text { John introduced }[\text { Ted }]_{\mathrm{F}} \text { to Mary }\right]\right]^{\mathrm{f}}=\{$ John introduced Bill to Mary, John introduced Sue to Mary, John introduced Tom to Mary

$=$ The set of propositions of the form "John introduced $\mathrm{x}$ to Mary".

Whenever there is a focus in a sentence, there is a focusing operator, represented as $\sim$. This operator comes with a variable argument, $\mathrm{C}$, which stands for a set of propositions ${ }^{8}$. The variable $\mathrm{C}$ needs an appropriate antecedent, and one possible antecedent for $\mathrm{C}$ is the denotation of the question. ${ }^{9}$

\subsection{Argument vs verb focus in Yorùbá}

In Yorùbá, sentences with focused arguments answer the corresponding whquestions:

a. Ta ni ó ra ìwé?

wh FOC 3sg buy book

'Who bought a/the book?'

Wh-question about subject

8 Essentially, Rooth's proposal is that focus in a sentence triggers a presupposition that the value of $C$ is a subset of $[[\mathrm{S}]]^{\mathrm{f}}$, which contains as its members the focused sentence, $[[\mathrm{S}]]^{0}$, plus at least one other proposition.

9 The denotation of the question is not the only possible antecedent for C. 
b. Adé ni ó ra ìwé.

Ade FOC 3sg buy book

'[Adé $]_{\mathrm{F}}$ bought a book..' Answer with subject focus felicitous

(32) a. Kí ni Adé rà __ ?

wh FOC A. buy

'What did Adé buy?'

Wh-question about object

b. İwé ni Adé rà

book FOC A. buy

'Adé bought $[\mathrm{a} / \text { the book }]_{\mathrm{F}}$ ' $\quad$ Answer with object focus felicitous

However, Yorùbá verb and VP focus does not answer the corresponding whquestions $^{10}$. (33a) and (33b) are infelicitous as answers to the context questions:

(33) a. Context question: What did Adé do with the book?

\#[Rírà $]_{\mathrm{F}}$ ni ó ra ìwé.

NOM-buy FOC 3sg. buy book.

'He [bought $]_{\mathrm{F}}$ the book.' Answer with verb focus infelicitous

b. Context question: What did Adé do?

\#[Rírà ìwé $]_{\mathrm{F}}$ ni ó ra ìwé.

NOM-buy FOC 3sg. buy book.

'He [bought a/the book $]_{F} . ' \quad$ Answer with VP focus infelicitous

The questions in (33) can be answered by using a plain sentence with no focus:

(34) Ó ra ìwé.

3 sg buy book

'He bought a/the book.'

Answer without focus felicitous

10 Kadmon (2001) characterizes the focus part of a sentence as "the answer to the question". Although question answer pairs are a diagnostic for focus, focus is felicitous in other contexts: verbs and VPs in these contexts are still considered to be focused. 
Examples of Yorùbá verb focus used in context are (35) and (36):

(35) Context: I'm carelessly about to spill coffee all over your new book. You take it away from me and say:

[Rírà $]_{F}$ ni mo ra ìwé yẹn!

NOM-buy FOC 1 sg buy book DET.

'I paid good money for that book!'

$\mathrm{V}$ focus felicitous

(36) Context: Our friend is wearing a really ugly dress that you know used to belong to me. You ask, "Did you give Sandra that dress?" I laugh and say:

Rárá, [títà $]_{\mathrm{F}}$ ni mo tà á fún un!

No, NOM-sell FOC 1 sg sell it her

'No, I sold it to her!' V focus felicitous

For focus of predicates, the antecedent for $\mathrm{C}$ (the variable introduced by focus) is not the denotation of a question. Predicate focus does not answer questions, so instead, the antecedent for $\mathrm{C}$ comes from elsewhere in the discourse.

\subsection{Required nominalization of verbs and discourse congruence}

Yorùbá predicate focus requires nominalization of the verb or VP. Predicates are nominalized via reduplication with a high tone vowel, $i$, which turns the verb or VP into "a gerund formed by prefixal reduplication" (Aboh 2003). There is also a copy of the verb or VP in the construal site ${ }^{11}$ :

(37) a. Mo ka ìwé.

1sg. read book

'I read a/the book.' Plain verb, non-focus

b. Kíka ni mo ka ìwé.

Read-NOM FOC 1sg read book

'I $[\mathrm{read}]_{\mathrm{F}}$ a/the book.' Reduplication, focused verb

11 The requirement that there be a full copy of the focused verb or VP in the construal site is attributed to a PF condition (Déchaine 2002): focus is disanaphoric; consequently the construal site is anaphoric, and reduced in some way (Williams 1997). The verbal category cannot be empty, but there is no equivalent in Yorùbá to English do/do so; therefore, a full copy is the only alternative. 
c. Kíka ìwé ni mo ka ìwé.

Read-NOM book FOC 1sg read book

'I $[\mathrm{read} \mathrm{a} / \text { the book }]_{\mathrm{F}}$ '

Reduplication, focused VP

The requirements of predication inversion force nominalization of focused verbs and VPs in Yorùbá (Déchaine, p. 4-6). In order to be raised to Spec., Infl., the predicate must be of a type that can occupy an argument position, specifically, a nominal.

Predicate focus is attested in Gùngbè (another Kwa language closely related to Yorùbá). Like in Yorùbá, the focused verb is moved to the sentenceinitial position, and there is a copy in-situ (Aboh):

[Gbá] $]_{F}$ [IP S'́ná gbá xwé ló ná Kòfí]

build S. build.PERF house DET for K.

S'́ná [built $]_{\mathrm{F}}$ the house for Kofi.

Gùngbè verb focus

Gùngbè verb focus contrasts with Yorùbá in that focused verbs are not nominalized. Aboh (2003) analyzes Gùngbè focus as $\mathrm{A}^{\prime}$-movement. The focused verb is extracted from its base-generated site and moved to the focus position, Spec., FocP. The contrast between Yorùbá and Gùngbè focus with respect to nominalization of verbs follows if Gùngbè focus is an $\mathrm{A}^{\prime}$-movement construction. If it is not nominal predication, it does not require a nominalized focus:

a. Gùngbè verb focus:

$\left[\text { FocP } V_{1}\right]_{F}\left[\right.$ IP $\left.\left.\ldots t_{1} \ldots\right]\right]$

$\mathrm{A}^{\prime}$-movement to Spec., FocP.

b. Yorùbá verb focus:

[DP SUBJ $_{\text {Nom }}$ PRED $]$

[Nom.] ni [ DP SUBJ $\left._{\text {PRED }}\right]$
Small clause

Predicate inversion

Yorùbá verb focus and Gùngbè verb focus have different felicity conditions. Yorùbá verb focus does not answer wh-questions, as was shown in (33). Gùngbè verb focus does answer wh-questions. (40) is felicitous in a context where someone asks the question "What did Sena do with the bread?" while pointing at the remains of the loaf (Enoch Aboh, p.c): 
(40) Context question: What did Sena do with the bread?

$$
\begin{aligned}
& \text { qùi } \text { IIP }_{\text {Sćnà qù̀ }} \quad \text { bléq ì ló]. } \\
& \text { eat S. eat.PERF bread DET } \\
& \text { 'Sena ATE the bread.' }
\end{aligned}
$$

I assume that the different felicity conditions of Yorùbá and Gùngbè verb focus are attributable to differences in the syntax of focus in each language. Yorùbá focus is inverse predication, and the coercion of verbs into nominalized events (gerunds) means they are not congruent to the wh-phrase in questions about verbs. Gùngbè focus is an $\mathrm{A}^{\prime}$-movement construction, which does not require nominalization.

\section{Conclusions}

I have examined some semantic and pragmatic properties of Yorùbá focus, and shown how they inform the understanding of its syntactic properties. Specifically, the absence of existence presuppositions and exhaustivity effects is incompatible with focus movement as defined by Kiss (1998), in which syntactic focus is restricted to the expression of identificational focus. These properties are compatible with the cleft analysis proposed by Déchaine (2002). However, Yorùbá focus differs from English cleft focus, which has both existence and exhaustivity presuppositions. Evidence from two Salish languages suggests that the properties of clefts are not uniform across languages. Comparison with Gùngbè suggests that the different felicity conditions of argument focus and predicate focus in Yorùbá is attributable to nominalization. The nominalization of focused Yorùbá verbs and VPs is cited by Déchaine as a requirement of predicate raising. 


\section{$7 \quad$ References}

Aboh, E.O. (2003) Focus constructions across Kwa. Trends in African Linguistics, 6: 7-22.

Ajíbóyè, O. (2005) Topics on Yorùbá nominal expressions. Thesis (PhD.)—UBC.

Awóyale, Y. (1985) Focus as an unbounded movement rule in Yorùbá. JOLAN, 3: 75-84.

Bisang, W. \& R. Sonaiya. (2000) Information structuring in Yorùbá. Linguistics, 38(1): 169197.

Carstens, V. (1985) Wh-movement in Yorùbá. Studies in African Linguistics, Suppl. 9: 39-44.

Davis, H., L. Matthewson, \& S. Shank. (2004) Clefts vs nominal predicates in two Salish languages. In: D. Gerdts et al.. (eds.) Studies in Salish Linguistics in Honor of M. Dale Kinkade, eds., University of Montana Press.

Davison, R. (1986) The pragmatic morpheme 'ni' in Yorùbá. CLS 22: 105-114.

Déchaine, R.M. (2002) Decomposing focus: evidence from Yorùbá. Triggers for Movement Workshop, Tilburg University, October 24-26.

Grice, P. (1975) Logic and conversation. In: Cole, P. and J.L. Morgan (eds.) Speech Acts. New York: Academic Press, 41-58.

Heycock, C. (1991) Layers of Predication: the Non-Lexical Syntax of Clauses. Thesis $(\mathrm{PhD})$ - University of Pennsylvania.

Kadmon, N. (2001) Formal pragmatics. Malden, Mass.: Blackwell.

Kiss, K.É. (1998) Identificational focus vs information focus. Language, 94(2) : 245-273.

Lambrecht, K. (2001) A framework for the analysis of cleft constructions. Linguistics, 39(3): 463-516.

Manfredi, V. (1995) Syntactic (de)composition of Yorùbá be and have. Nash, L. \& G. Tsoulas (eds.) Langues et Grammaire, 237-52.

Percus, O. (1997) Prying open the cleft. NELS 27: 337-351.

Pesetsky, D. (1987) WH in-situ: movement and unselective binding. In: Reuland, E. and A. ter Meulen (eds.). The Representation of (In)definiteness. Cambridge, MIT Press, 98129.

Rooth, M. (1996) Focus. In: Lappin, S. (ed.) Handbook of Contemporary Semantic Theory. Oxford: Blackwell, 271-297.

Yusuf, O. (1990) Yorùbá copula ni. Journal of West African Linguistics, 20(1): 83-93. 